\begin{tabular}{|l|l|l||}
\hline \multicolumn{2}{|c|}{ PublisherInfo } \\
\hline \hline PublisherName & $:$ & BioMed Central \\
\hline \hline PublisherLocation & $:$ & London \\
\hline \hline PublisherImprintName & $:$ & BioMed Central \\
\hline \hline
\end{tabular}

\title{
Researchers boycott Cell Press
}

\begin{tabular}{|l|l|l||}
\hline \multicolumn{2}{|c|}{ ArticleInfo } \\
\hline \hline ArticleID & $:$ & 4864 \\
\hline \hline ArticleDOI & $:$ & $10.1186 /$ gb-spotlight-20031024-02 \\
\hline \hline ArticleCitationID & $:$ & spotlight-20031024-02 \\
\hline \hline ArticleSequenceNumber & $:$ & 216 \\
\hline \hline ArticleCategory & $:$ & Research news \\
\hline ArticleFirstPage & $:$ & 1 \\
\hline \hline ArticleLastPage & $:$ & 4 \\
\hline \hline & & RegistrationDate : 2003-10-24 \\
ArticleHistory & $:$ & OnlineDate \\
\hline \hline ArticleCopyright & $:$ & BioMed Central Ltd2003-10-24 \\
\hline \hline ArticleGrants & $:$ & \\
\hline \hline ArticleContext & $:$ & 130594411 \\
\hline \hline
\end{tabular}




\section{Alison McCook}

Email: abmccook@yahoo.com

Researchers at the University of California, San Francisco (UCSF), have written a letter asking their colleagues worldwide to boycott all journals published by Cell Press - including Cell, Molecular Cell, and Neuron - to protest the high price of electronic access.

In the letter, Peter Walter and Keith Yamamoto write that Elsevier, owner of Cell Press, is asking the University of California for an additional $\$ 90,000$ per year to provide electronic access to the six Cell Press titles - when the university already paid Elsevier $\$ 8$ million for online access to its other journals in 2002 alone.

Walter told us that he and Yamamoto decided to write the letter when they lost access to Cell Press journals after moving to a campus that was 20 minutes away from the main campus, which carries paper copies of the journals. They then learned that the university had been trying unsuccessfully to reach a deal with Elsevier for electronic access since 1998.

The letter urges their colleagues to resign from the editorial boards of Cell Press, to stop submitting papers, and to refuse to review manuscripts for the journals, which also include Developmental Cell, Cancer Cell, and Immunity. While publishing a paper in the prestigious Cell Press titles is a career goal for many researchers, Walter told us that there is little glory in publishing in an outlet that is inaccessible to others. "There's no point to having the little gold star attached to your papers if your colleagues can't read them," he said.

In response to the letter, Lynne Herndon, president and chief executive officer of Cell Press, distributed an E-mail last Friday (October 17) offering all UC researchers who registered a username and password free electronic access to Cell Press titles through the end of the year.

Walter and Yamamoto responded Monday (October 20) with another E-mail, reminding UC researchers that Cell Press had offered trial electronic access to the journals before, then removed that access when negotiations with the university fell apart. Consequently, they urged their colleagues to maintain the boycott.

Walter added that he would be satisfied with even a small response from the research community. "Even if [Elsevier] only gets five papers less," he said, he believed the company would see that what it is doing is wrong.

On Wednesday (October 22), Herndon released another statement calling the $\$ 90,000$ annual fee for the six Cell Press journals "an excellent value," equivalent to roughly $\$ 1.50$ per journal per year for each active user within the UC system.

Herndon told us she hopes that the latest statement will encourage scientists to put the prospect of a boycott on hold until they see the result of talks with the university, and will "pave the way for successful negotiations between Cell Press" and the California Digital Library, which handles journal contracts for the university. 
However, the California Digital Library has rejected Cell Press's latest offer. Karen Butter, librarian at the University of California, San Francisco, told us that UCSF pays only $\$ 5000$ per year for electronic access to the New England Journal of Medicine. The university rejected Cell Press's offer because Elsevier already receives a lot of money from the university, she said, and the company has not adequately explained why they need more for the additional journals. She added that she hopes the boycott forces Elsevier to "think twice about their pricing strategy" because we can't afford it."

Walter said that so far, his colleagues' reactions to the call to boycott have been "incredibly positive." However, one researcher, who spoke on the condition of anonymity, cautioned that the Public Library of Science (PloS) tried a similar technique a few years ago, in which they asked researchers to boycott all journals that did not provide free access to their material. Many journals did not comply with that request, and no significant boycott occurred, he noted. "The track record [for boycotts] is not very good," the researcher said. "And if PLoS failed, these guys might fail."

Matthew Scott of Stanford University told us he had passed the letter onto some colleagues, who seemed "largely quite enthusiastic about moves in this direction." He noted that Stanford currently has electronic access to the journals, but access has been spotty because of the cost.

He predicted that over time, researchers will submit fewer papers to costly journals and more to journals that provide free access to material. "People will turn more and more to that model, because they're so fed up with being denied access," he said.

Last week the Public Library of Science launched PLoS Biology, the first of a proposed cluster of journals that provide readers open access to the material. Vivian Siegel, the executive director of the journal, is a former editor at Cell.

PLoS plans to charge $\$ 1500$ per submitted article. BioMed Central charges $\$ 500-\$ 1000$ per article at present and recoups costs through value-added services. BioMed Central also offers institutional memberships that allow the institution's researchers to publish in BioMed Central's 90-plus journals without paying the fee.

\section{References}

1. Cell Press, [http://www.cellpress.com]

2. Peter Walter, [http://www.ucsf.edu/pibs/faculty/walter.html] 
3. Keith Yamamoto, [http://cc.ucsf.edu/people/yamamoto_keith.html]

4. California Digital Library, [http://www.cdlib.org/]

5. Matthew Scott, [http://www.hhmi.org/research/investigators/scottm.html]

6. Walgate R: PLoS Biology launches The Scientist, October 10, 2003., [http://www.the-scientist.com/ news/20031010/10/]

7. Hagan P: PLoS plans to launch its own journals The Scientist, September 7, 2001., [http://www.thescientist.com/news/20010907/04/]

8. Mason B: Cell editor joins PLoS The Scientist, January 13, 2003., [http://www.the-scientist.com/ news/20030113/05/]

9. Public Library of Science, [http://www.publiclibraryofscience.org/]

10. BioMed Central, [http://www.biomedcentral.com] 